Article

\title{
Crop Rotation Compared with Continuous Rye Cropping for Weed Biodiversity and Rye Yield. A Case Study of a Long-Term Experiment in Poland
}

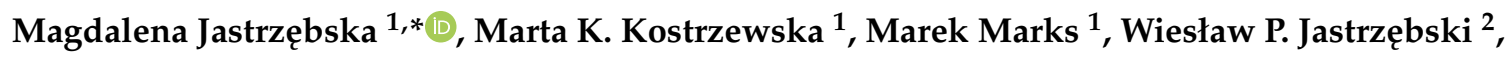 \\ Kinga Treder ${ }^{1}\left[\right.$ and Przemysław Makowski ${ }^{1}$ \\ 1 Department of Agroecosystems, Faculty of Environmental Management and Agriculture, University of \\ Warmia and Mazury in Olsztyn, Plac Łódzki 3, 10-718 Olsztyn, Poland; \\ marta.kostrzewska@uwm.edu.pl (M.K.K.); marek.marks@uwm.edu.pl (M.M.); \\ kinga.treder@uwm.edu.pl (K.T.); przemyslaw.makowski@uwm.edu.pl (P.M.) \\ 2 Department of Botany and Nature Protection, Faculty of Biology and Biotechnology, University of Warmia \\ and Mazury in Olsztyn, Plac Łódzki 1, 10-727 Olsztyn, Poland; w.jastrzebski@uwm.edu.pl \\ * Correspondence: jama@uwm.edu.pl; Tel.: +48-89-523-4829
}

Received: 31 August 2019; Accepted: 13 October 2019; Published: 16 October 2019

\begin{abstract}
In recent years, sustainable agriculture has revitalized interest in crop rotations and their effects on crop performance and agroecosystem biodiversity, including weeds. This article used winter rye as an example and focused on the crop rotation (CR) impact on species, taxonomic and functional diversity of weed communities and analysed the contribution of crop rotation to protecting yield and regulating weed abundance. Long-term continuous rye cropping (CC) provided a background for comparison. Two variants of plant protection were also adopted: herbicide application $(\mathrm{H}+)$ and no plant protection $(\mathrm{H}-)$. The data from the 10th, 30th and 50th years of the experiment were included in the analysis. Diversified crop rotation with no chemical protection resulted in a satisfactory rye yield and reduced weed abundance-especially problem species-without a decrease in weed species diversity or functional diversity. When rye was grown under crop rotation, the herbicide application had no effect on yield protection, but it was harmful to weed biodiversity. The rye yield correlated negatively with weed biomass, but did not show a link with weed biodiversity. Continuation of long-term experiments as a research basis for contemporary and future scientific challenges is necessary.
\end{abstract}

Keywords: cropping system; continuous monoculture; species richness; Shannon-Wiener index; Warwick-Clarke taxonomic distinctness index; Rao's quadratic entropy; Apera spica-venti (L.) P. Beauv.; Centaurea cyanus L.

\section{Introduction}

In recent decades, agronomical innovations, market preferences and specialist food processing chains have forced fundamental changes in crop rotation practices in conventional farming systems [1]. This has resulted in the dominance of a limited number of cash crops and short-term management plans. Classical crop rotation systems became uncommon, while short rotations and flexible sequence cropping have been practiced. Frequently, the same crop species has been grown on the same field for several consecutive years. Simplifications of crop rotations, both in Poland and in the world, were mainly oriented towards increasing the cereal percentage among growing crops [2-4].

Most crop species react negatively to continuous cultivation on the same field or after a biologically related species. This contributes to the intensification and overlapping of many unfavourable phenomena, including: excessive growth of weed infestation, development of fungal diseases of 
the root system, stem base, leaves and spikes, multiplication of specialised pests in the soil, change of microbiological and biochemical activity of the soil, deterioration of its chemical and physical properties and, finally, 'soil fatigue'. These findings have been confirmed by studies carried out on short rotations and long-term continuous cropping [5-12] which showed that continuous cropping of a single species is the most unfavourable crop succession system.

It should be noted that the usefulness of prolonged experiments with continuous cropping may be far from practical. However, long-term field experiments are extremely important in monitoring and interpreting changes resulting from agrotechnical factors [13,14]. According to Niewiadomski [15], to provide reliable practical information, researchers should thoroughly understand how the species reacts to the worst possible crop succession.

It is worth noting that in recent years, the value of long-term field experiments has increased among researchers world-wide [14]. The oldest and most well-known experiments have been conducted in Rothamsted (UK) since 1843 with continuous winter wheat (Broadbalk) and continuous spring barley (Hoosfield) conducted since 1852 [14], along with the Eternal Rye trial in Halle (Germany), started in 1878 [16]. The longest-term experiment in Poland is the continuous cropping of rye and potato in Skierniewice (since 1923), followed by other continuous cropping experiments in Brody (since 1957), Bałcyny (since 1968) and Swojec (since 1971) [17].

Long-term continuous cropping leads to a decrease in crop yields. Efficiency can be maintained by using plant protection products, fertilisers and growth regulators, but their large-scale use is not neutral to the environment. Intensive chemical protection often only has a temporary effect and results in increasing the rate of agrophage resistance to biologically active substances [18].

In recent years, sustainable agriculture has revitalized the interest in crop rotations and their effects on crop performance to obtain the most profitable and effective agriculture [19]. For agronomists, it is widely known that crop rotations fulfil important agronomic functions [20]. Crop planning based on multiple crops with rotation benefits reduces the need for synthetic chemicals, improves the soil structure, increases the biodiversity in the farm, enhances the resilience of the farmer to adverse environmental biotic and abiotic conditions and also improves the diet of the local community [19].

Weeds represent one of the most important biological constraints for crop production as they affect the quantity of the harvest product as a result of competition [21]. They can also host many pests and pathogens, make harvesting more difficult and reduce crop yield quality [22]. On the other hand, weeds are the basis for the whole food chain in the agro-ecosystem and provide a range of important ecosystem services $[23,24]$. However, for several decades there were attempts to eliminate them almost completely, until they began to be seen as an element of biodiversity and a factor sustaining biodiversity through trophic and paratrophic relationships.

In recent decades, application of intensive chemical protection against weeds has increased, especially in simplified crop sequences, together with increased doses of mineral fertilizers $[25,26]$. The simplification of cropping systems and increased inputs of agro-chemicals has led to the dominance of a few competitive, highly adapted and widely distributed weed species [27]. At the same time, since the middle of the 20th century, a decline in weed species richness in agro-ecosystems by $64 \%$ has been noted [21]. Many of the weed species became highly endangered or even extinct [28,29].

Considering the growing human population and its requirements, balancing the need to protect crops and sustain the biodiversity of the living world is a major challenge for modern and future agriculture $[24,30]$. A new approach to biodiversity-friendly weed management requires effective control of highly competitive problem species while maintaining beneficial species at economically acceptable levels [25]. Storkey and Neve [27] claim that a more diverse weed community is an indicator of agronomic and environmental sustainability. Crop rotation is a recognised tool for weed abundance control $[5,31]$ and it is also argued that this cropping system has considerable impact on relations within agrobiocenosis, and consequently on the floristic composition and diversity of weed communities [26].

Weed biodiversity is nowadays most often defined at its species level and expressed as a species number or using Shannon-Wiener's indices $[25,27,32]$. These indicators treat all species present in the 
community equally, regardless of their taxonomic affinity or the role they play in the ecosystem, and in the case of the Shannon-Wiener index, the relative abundance of each species additionally determines the species' importance. Taxonomic diversity is based on the representation of lower-rank taxa within higher-rank taxa [33]. Taxonomic diversity of weed communities has been more frequently determined by distinguishing mono- and dicotyledonous weed species [34]. However, relatively recently, easy to calculate indices based on taxonomic differentiation of organisms within a community have been proposed [35]. It is known that under disturbances in biota communities their taxonomic spectrum is reduced and, in extreme situations, only closely-related species, belonging to even one genus, may be present [33]. Taxonomic diversity can therefore be used as a measure of the stress exerted on weed communities by various factors. A different approach to the weed biodiversity issue has a functional dimension. Functional diversity is understood through the concept of ecological niche and based on organisms' traits that influence the ecosystem functioning [36]. Species with a similar impact on a particular process(es) in an ecosystem or presenting a similar response to environmental factors are grouped into so-called functional groups [37]. Functional groups are defined based on one or more traits [38]. The trait selection is normally arbitrary, which is considered a weakness of the concept [39]. It largely depends on the link between the trait(s) and the analysed species' function(s) in the ecosystem, for which the species in the group can be qualified as mutually substitutable. World literature draws attention to the need for research on weed communities' role in maintaining biodiversity accompanying agrophytocenoses [24]. On the other hand, the possibility of making weed control cheaper and easier through the use of strategies for functional groups rather than individual species is emphasised [40,41]. Integrating species abundance into the calculation of different biodiversity indices remains a separate issue. Considering that weed competitiveness against crops is rather a function of their biomass than density, as even quite numerous but small weed seedlings are of little harm, using biomass as the indices' basis seems more reasonable [42].

Adopting winter rye as an example, this article focuses on comparing the impact of crop rotation and long-term continuous cropping on species, taxonomic and functional diversity of weed communities and also aims to recall the contribution of crop rotation to protecting the yield and regulating weed abundance. In addition to the crop sequence, the plant protection against weeds versus no plant protection was also taken into account. It was assumed that a cereal growing in diversified crop rotation, even without chemical protection, would not only guarantee a satisfactory yield level, but would also limit weed competition without a dramatic reduction in their biodiversity.

\section{Materials and Methods}

\subsection{Site Description}

The study was carried out in a long-term field experiment conducted on the fields of the Production and Experimental Plant 'Bałcyny' Sp. z o.o. in Bałcyny, near Ostróda (Warmińsko-Mazurskie Province, Poland, $53.60^{\circ} \mathrm{N}, 19.85^{\circ} \mathrm{E}, 136.9 \mathrm{~m}$ above sea level The geomorphological features of the region were formed mostly during the last glaciation (Vistulian) [43]. The area is dominated by soils developed from boulder clays, and glacial sands and gravels. The experiment is located in a slightly undulating area, on Luvisols, formed from silty light loam. The content of clay particles $(<0.002 \mathrm{~mm})$ in the $0-30$ $\mathrm{cm}$ soil layer range from $2 \%$ to $4 \%$, floatable particles $(0.02-0.002 \mathrm{~mm}$ ) range from $17 \%$ to $22 \%$, and silt (0.1-0.02 $\mathrm{mm}$ ) ranges from $26 \%$ to $39 \%$ [11]. Due to the location in the temperate warm transitional zone [44], the climate is characterized by highly variable weather and significant fluctuations in the course of the seasons in consecutive years. Rainfall is fairly evenly distributed throughout the year, although there are irregular short-term dry spells and drought periods, as well as heavy rainfall. In Bałcyny, dry spells, which are the most threatening for vegetation, appear in July and August [45]. As in the whole territory of Poland, six thermal seasons are distinguished in the region of Bałcyny: winter $\left(\mathrm{t}<0^{\circ} \mathrm{C}\right)$, early spring $\left(0^{\circ}-5^{\circ} \mathrm{C}\right)$, spring $\left(5^{\circ}-15^{\circ} \mathrm{C}\right)$, summer $\left(\mathrm{t}>15^{\circ} \mathrm{C}\right)$, autumn $\left(5^{\circ}-15^{\circ} \mathrm{C}\right)$ and early winter $\left(0^{\circ}-5^{\circ} \mathrm{C}\right)$ [46]. The average length of the vegetation period was estimated to be 215 days and 
the average number of frost-free days to be 170 [47]. Monthly average air temperatures, as well as monthly rainfall totals in the research periods according to the Meteorological Station in Bałcyny, are shown in Table 1.

Table 1. Atmospheric precipitation and daily air temperature during the study periods according to the Meteorological Station in Bałcyny.

\begin{tabular}{|c|c|c|c|c|c|c|c|c|c|c|c|c|}
\hline \multirow{2}{*}{ Growing Season } & \multicolumn{12}{|c|}{ Month } \\
\hline & IX & $X$ & XI & XII & I & II & III & IV & V & VI & VII & VIII \\
\hline \multicolumn{13}{|c|}{ Atmospheric Precipitation (mm) } \\
\hline 1976/1977 & 60.1 & 38.8 & 44.2 & 58.6 & 44.7 & 38.1 & 35.3 & 89.9 & 84.9 & 57.6 & 128.8 & 108.7 \\
\hline $1996 / 1997$ & 45.1 & 61.9 & 41.3 & 4.9 & 4.7 & 31.5 & 31.2 & 22.6 & 99.0 & 71.7 & 187.6 & 25.1 \\
\hline $2016 / 2017$ & 17.1 & 96.3 & 78.2 & 77.8 & 15.8 & 40.5 & 53.0 & 52.1 & 34.0 & 109.9 & 106.1 & 54.8 \\
\hline \multicolumn{13}{|c|}{ Daily air temperature $\left({ }^{\circ} \mathrm{C}\right)$} \\
\hline $1976 / 1977$ & 12.0 & 5.7 & 4.3 & -1.8 & -1.8 & -1.2 & 4.2 & 5.1 & 11.6 & 16.8 & 15.6 & 16.1 \\
\hline $1996 / 1997$ & 9.7 & 8.7 & 5.0 & -6.0 & -4.8 & 0.9 & 2.1 & 4.0 & 11.4 & 15.7 & 16.9 & 18.3 \\
\hline $2016 / 2017$ & 14.7 & 6.9 & 2.5 & 1.0 & -3.2 & -1.2 & 5.1 & 6.7 & 13.1 & 16.7 & 17.3 & 18.7 \\
\hline
\end{tabular}

The field experiment was established in 1967 to investigate the reaction of nine arable plant species (winter rye, winter wheat, spring barley, oats, maize, sugar beet, faba bean, winter rape, and fibre flax) to continuous cropping. In 1972, all crop fields were divided into two parts. Continuous cropping has been maintained on one part of each field and on the other part crop rotation was started. A field of potato was added, and two five-field crop rotations were generated as a contrast to continuous cropping systems. In 1993, fields of continuous peas and continuous winter triticale were added, and the crop rotations were transformed into six-field systems. In addition, other factors were tested throughout the experiment: different cultivars, different fertilisation and plant protection levels. In the experiment, there was a cyclical exchange of crop cultivars, i.e., after each rotation (as assigned to the region according to Research Centre for Cultivar Testing (COBORU) in Słupia Wielka recommendations). The use of pesticides has also been regularly updated, in accordance with the recommendations of the Institute for Plant Protection-National Research Institute in Poznań.

\subsection{Experimental Design and Agronomic Management}

In this study, winter rye was the research subject and two experimental factors were investigated, each with two levels: a cropping system, comparing winter rye growing in crop rotation (CR) versus winter rye continuous cropping (CC) and the plant protection level, where the herbicide application $(\mathrm{H}+)$ was compared to the no plant protection treatment $(\mathrm{H}-)$.

Throughout the experiment, the plant sequence in the target crop rotation was modified and in the following years it was as follows: in 1972-1977: potato-maize-oats-fibre flax-winter rye, in 1978-1992: potato-oats—fibre flax-winter rye-maize, and since 1993: potato-oats-fibre flax — winter rye-faba bean-winter triticale. Since 1983, farmyard manure (FYM) has been used in the experiment: in crop rotation before potato planting (30 t/ha), and in continuous rye every three years (15 t/ha). In both cases, it is applied in autumn and covered with pre-winter ploughing.

For the analysis, data from three points on the time-axis were used: from the 10th, 30th and 50th year of the experiment. Basic agricultural data for winter rye in the years under consideration are presented in Table 2, and the herbicide treatment characteristics are in Table 3. 
Table 2. Basic agricultural data for winter rye in the years under consideration.

\begin{tabular}{|c|c|c|c|}
\hline Item & 1977 & 1997 & 2017 \\
\hline Rye cultivar & Pancerne & Dańkowskie Złote & Dańkowskie Diament \\
\hline Soil tillage system & plough tillage & plough tillage & plough tillage \\
\hline $\begin{array}{l}\text { Expected plant density at } \\
\text { emergence (No./m²) }\end{array}$ & 300 & 450 & 400 \\
\hline \multicolumn{4}{|l|}{ Mineral fertilisation } \\
\hline$-\mathrm{P}_{2} \mathrm{O}_{5}(\mathrm{~kg} / \mathrm{ha})$ & $60^{1}$ & $70^{1}$ & $70^{1}$ \\
\hline$-\mathrm{K}_{2} \mathrm{O}(\mathrm{kg} / \mathrm{ha})$ & $80^{1}$ & $100^{1}$ & $100^{1}$ \\
\hline -N (kg/ha) & $60\left(30^{2}+30^{3}\right)$ & $70\left(50^{2}+20^{3}\right)$ & $70\left(50^{2}+20^{3}\right)$ \\
\hline \multicolumn{4}{|l|}{ Plant protection } \\
\hline -herbicides & $-/+$ & $-/+$ & $-/+$ \\
\hline -other pesticides & - & - & - \\
\hline Sowing date & 15 September, 1976 & 18 September, 1996 & 19 September, 2016 \\
\hline Harvest date & 16 August, 1977 & 5 August, 1997 & 4 August, 2017 \\
\hline
\end{tabular}

Table 3. Characteristics of herbicides used for winter rye protection in the years under consideration.

\begin{tabular}{ccccc}
\hline Year & Trade Name & Active Ingredient & Rate & Application \\
\hline 1977 & Igran 50 & Terbutryn & $4.0 \mathrm{~kg} / \mathrm{ha}$ & $\begin{array}{c}\text { Autumn (17 September, 1976), } \\
\text { pre-emergence }\end{array}$ \\
\hline 1997 & Cougar 600 SC & Diflufenican + isoproturon & $1.2 \mathrm{~L} / \mathrm{ha}$ & $\begin{array}{c}\text { Autumn (20 September, 1996), } \\
\text { pre-emergence }\end{array}$ \\
\hline 2017 & Trinity 590 SC & $\begin{array}{c}\text { Diflufenican + chlorotoluron } \\
+ \text { pendimethalin }\end{array}$ & $2.0 \mathrm{~L} / \mathrm{ha}$ & $\begin{array}{c}\text { Autumn (27 October, 2016), } \\
\text { before rye tillering }\end{array}$ \\
\hline
\end{tabular}

The experiment was established in a split-plot design with three replications. The area of a single experimental plot was $27 \mathrm{~m}^{2}$.

\subsection{Data Collection}

\subsubsection{Weed Species and Abundance}

Weeds were sampled from a randomly determined area of $1 \mathrm{~m}^{2}$ from each plot prior to harvesting the winter rye. In each sample, weed roots were separated from the above-ground parts and removed. In 1977, only dominating weed species ( $>5 \%$ of the total weed biomass under CC-H-) were identified in the samples and weighted separately. Other species were included into total weed biomass. In 1997 and 2017, all weed species were identified, segregated and weighed separately.

\subsubsection{Weed Biodiversity}

On the basis of samples collected from particular plots in 1997 and 2017, the following biodiversity measures were established: species richness $(S)$, species diversity index $\left(H^{\prime}\right.$-Shannon-Wiener index [48]), taxonomic distinctness index $(\Delta+-$ Warwick and Clarke index [35]), and functional diversity index ( $Q$ - Rao's quadratic entropy [49]).

The number of species per $\mathrm{m}^{2}$ was adopted as the species richness $(S)$. Other biodiversity indexes were calculated according to the following formulas:

$$
H^{\prime}=-\sum_{i=1}^{S}\left(p_{i} \ln p_{i}\right),
$$




$$
\begin{aligned}
\Delta^{+} & =\frac{\sum \sum_{i<j} w_{i j} x_{i} x_{j}}{\sum \sum_{i<j} x_{i} x_{j}}, \\
Q & =\sum_{i=1}^{S-1} \sum_{j=i+1}^{S} d_{\mathrm{ij}} p_{\mathrm{i}} p_{\mathrm{j}},
\end{aligned}
$$

where $p_{i}$ is the proportion of the $i$-th species biomass to the community biomass (see also Table S1), $w_{i j}$ is the 'distinctness weight' of the $i$-th and $j$-th species according to the hierarchical taxonomic classification: $w=0$ for biomass of individuals within the same species; $w=1$ for different species within the same genus; $w=2$ for species within the same family but different genera; $w=3$ for species within the same order but different family; $w=4$ for species within the same class but in different order; $w=5$ for species within the same division but different class; $w=6$ for species in different divisions of the plant kingdom; the basic taxonomic categories in the plant kingdom as well as systematic positions of individual species and Latin names followed Mirek et al. [50] (see also Table S2); $x_{i}$ is the biomass of the $i$-th species in the community; $x_{j}$ is the biomass of the $j$-th species in the community and $d_{i j}$ is the dissimilarity between species $i$ and $j$, measured by the Euclidean distance based on six arbitrarily chosen functional traits (Table 4 and Table S3).

\begin{tabular}{|c|c|c|c|}
\hline Plant Trait & Trait Characteristics & Rationale & Data Source \\
\hline Maximum plant height & Quantitative, m & $\begin{array}{l}\text { light and water acquisition, } \\
\text { competition ability }\end{array}$ & {$[51,52]$} \\
\hline Growth habit & $\begin{array}{l}\text { Qualitative: erect, } \\
\text { prostrate, climbing }\end{array}$ & $\begin{array}{l}\text { resource acquisition, space } \\
\text { use, competition ability }\end{array}$ & $\begin{array}{c}{[51], \text { own }} \\
\text { observations }\end{array}$ \\
\hline Specific leaf area (SLA) & Quantitative, $\mathrm{mm}^{2} / \mathrm{mg}$ & $\begin{array}{l}\text { resource acquisition, } \\
\text { stress tolerance, } \\
\text { competition ability }\end{array}$ & {$[51]^{1}$} \\
\hline Season of emergence & $\begin{array}{l}\text { Qualitative: autumn, spring, } \\
\text { autumn or spring }\end{array}$ & $\begin{array}{l}\text { crop sowing dates, } \\
\text { competition start time }\end{array}$ & $\begin{array}{c}{[52], \text { own }} \\
\text { observations }\end{array}$ \\
\hline Seed number & $\begin{array}{l}\text { Quantitative, No./shoot: no } \\
\text { seeds, }<100 ; 100-1000 ; \\
\text { 1000-10,000; 10,000-100,000; } \\
>100,000\end{array}$ & $\begin{array}{l}\text { propagation, colonisation } \\
\text { capacity, future weed density }\end{array}$ & $\begin{array}{c}{[51], \text { own }} \\
\text { observations }\end{array}$ \\
\hline $\begin{array}{l}\text { Ecological trophic } \\
\text { indicator value (Tr) }\end{array}$ & Quantitative, 1-5 scale & $\begin{array}{l}\text { trophic requirements, } \\
\text { competition ability }\end{array}$ & {$[53,54]^{2}$} \\
\hline
\end{tabular}

Table 4. Weed functional traits used to calculate functional diversity index $(Q)$.

The qualitative (species) and quantitative structure of weed communities was compared using the similarity index (SI), according to the formula by Sørensen [55]:

$$
S I=\frac{2 c}{a+b},
$$

where $c$ is the number of species shared by the two communities or total biomass of species shared by the two communities; $a$ is the number of species or total biomass of species in the first community and $b$ is the number of species or total biomass of species in the second community.

The calculations of Euclidean distance on the basis of chosen functional traits were supported by Statistica software [56] and other calculations were done using Microsoft Excel [57].

\subsubsection{Grain Yield and Yield Structure Components}

The yield was assessed based on the amount of grain obtained from individual plots. The results were calculated per 1 ha and with a grain moisture of $15 \%$. The following yield structure components 
were determined: spike density (the density of productive tillers per $1 \mathrm{~m}^{2}$ ) prior to wheat harvest, with the frame method (dimensions of a frame $0.50 \mathrm{~m} \times 0.50 \mathrm{~m}$ ); the grain number per spike based on the measurements on 20 plants sampled from each plot and the weight of 1000 grains (TGW) based on grain samples taken during combine harvesting.

\subsection{Statistical Analysis}

The results were submitted to two-factorial analysis of variance (ANOVA). It was performed for each year separately, assuming experimental factors (cropping system and plant protection level) to be fixed and blocks (three replications) to be random. The changes in variable values between years within CC-H-, CC-H+, CR-H- and CR-H+ variants (treatments) were established in additional separate one-way analyses (fixed: years, random: blocks). The normality of variable distribution was checked using the Shapiro-Wilk W-test and the homogeneity of variance using Levene's test. To homogenize variances, weed biomass, $H^{\prime}$ and $Q$ values were transformed using natural logarithms $(\ln (x+1))$, and $\Delta+$ values were square-root transformed. Other variables were not transformed. The differences between objects were evaluated using Duncan's test. The relationships between the variables were expressed using simple correlation coefficients. When variables were transformed, both transformed and untransformed data were used for correlation. The calculations were supported by Statistica software [56]. The tables present average values from three replications (original and transformed).

\section{Results and Discussion}

\subsection{Weed Biomass}

In all three selected years (time points), the highest weed biomass was found under CC-Htreatment (Table 5), which is not surprising considering other studies [5,58,59]. Taking into account the FYM application program in the experiment and the fact that FYM is a source of nutrients and weed seeds, it should be considered whether the amount and timing of/distance from FYM application affected the rye weed infestation. The signs of this impact should be manifested primarily under CC-H-. However, they were imperceptible in our research. This confirms that the cropping system (crop sequence) effects and herbicides have a stronger effect on weed infestation than fertilisation [58]. It is significant that under 30- and 50-year-old CC-H- no increase in weed biomass was observed in comparison with 10-year CC-H-. Other studies show that a strong increase in weed infestation is often observed in the early years of CC with no plant protection, but in longer-lasting CC, the growth of weed biomass is already weaker or even inhibited by competitive processes between weed species [58]. Weed abundance fluctuations can be noted as a result of weather conditions [34,58]. This could indicate that the weed community has "adapted" to the persistent stress factor and that a relative stabilisation at a different level than the initial level has occurred [60].

The CR-H- treatment significantly reduced weed biomass in each of the studied years, which is consistent with other reports $[5,58]$, and this reduction increased with time, which is evidenced in particular by the relative numbers.

The importance of $\mathrm{H}+$ in weed infestation control in $\mathrm{CC}(\mathrm{CC}-\mathrm{H}+)$ has weakened over time. In 1977, the CC-H+ treatment considerably reduced weed biomass and its effectiveness was significantly higher than CR-H-. In 1997, the CC-H+ also significantly reduced the weed biomass, and it was a reduction to the level guaranteed by the $\mathrm{CR}-\mathrm{H}-$, of which the weed control function increased. Relative numbers, however, indicate a slightly weaker CC-H+ performance in 1997 than in 1977. In 2017, the weed biomass reduction under CC-H+ compared to CC-H- was statistically negligible. Two different opinions can be found in the literature: one that herbicides cannot reduce the weed infestation of continuous cereal cropping to the weed level achieved in chemically unprotected crop rotation, and another that such a possibility indeed exists [58]. The 2017 study results show that after 50 years of rye CC, despite regular herbicide updates, chemical plant protection against weeds became ineffective 
in total weed biomass reduction. What is more, herbicide-resistant weed species expanded after out-competing the more sensitive taxa affected by herbicides.

Table 5. Weed biomass $\left(\mathrm{g} / \mathrm{m}^{2}\right)$ in winter rye fields (relative numbers in brackets are \% of CC-H- effects), including problem species biomass.

\begin{tabular}{|c|c|c|c|c|c|c|c|c|}
\hline \multirow{3}{*}{ Item } & \multirow{3}{*}{$\begin{array}{l}\text { Cropping } \\
\text { System }\end{array}$} & \multirow{3}{*}{$\begin{array}{c}\text { Plant } \\
\text { Protection }\end{array}$} & \multicolumn{2}{|c|}{1977} & \multicolumn{2}{|c|}{1997} & \multicolumn{2}{|c|}{2017} \\
\hline & & & \multicolumn{6}{|c|}{ Data } \\
\hline & & & Original & Transformed & Original & Transformed & Original & Transformed \\
\hline \multirow[t]{4}{*}{$\begin{array}{c}\text { Total } \\
\text { biomass }\end{array}$} & $\mathrm{CC}$ & $\mathrm{H}-$ & $366(100)$ & $5.91^{\mathrm{a}, 1}$ & $227(100)$ & $5.42^{\mathrm{a}}$ & $330(100)$ & $5.75^{\mathrm{a}}$ \\
\hline & & $\mathrm{H}+$ & $58(16)$ & $4.08^{c}$ & $53(23)$ & $3.82^{b}$ & $253(77)$ & $5.51^{\mathrm{a} \uparrow}$ \\
\hline & $\mathrm{CR}$ & $\mathrm{H}-$ & $186(51)$ & $5.23^{b}$ & $45(20)$ & $3.78^{b \downarrow}$ & $31(9)$ & $3.40^{\mathrm{b}}$ \\
\hline & & $\mathrm{H}+$ & $22(6)$ & $3.14^{d}$ & $0(0)$ & $0.03^{c \downarrow}$ & $3(1)$ & $1.26^{\mathrm{c} \uparrow}$ \\
\hline \multirow{4}{*}{$\begin{array}{c}\text { Apera } \\
\text { spica-venti } \\
\text { L.) P. Beauv. }\end{array}$} & $\mathrm{CC}$ & $\mathrm{H}-$ & 199 & $5.30^{a}$ & 94 & $4.55^{\mathrm{a}}$ & 168 & $5.10^{\mathrm{a}}$ \\
\hline & & $\mathrm{H}+$ & 33 & $3.53^{b}$ & 16 & $2.48^{\mathrm{b} \downarrow}$ & 81 & $4.19^{\mathrm{b} \uparrow}$ \\
\hline & $\mathrm{CR}$ & $\mathrm{H}-$ & 16 & $2.83^{b}$ & 3 & $0.92^{c \downarrow}$ & 3 & $1.18^{\mathrm{c}}$ \\
\hline & & $\mathrm{H}+$ & 1 & $0.69^{\mathrm{c}}$ & 0 & $0.00^{\mathrm{c}}$ & 1 & $0.33^{c}$ \\
\hline \multirow{4}{*}{$\begin{array}{l}\text { Centaurea } \\
\text { Cyanus L. }\end{array}$} & $\mathrm{CC}$ & $\mathrm{H}-$ & 77 & $4.36^{\mathrm{a}}$ & 88 & $4.41^{\mathrm{a}}$ & 120 & $5.03^{a}$ \\
\hline & & $\mathrm{H}+$ & 5 & $1.79^{\mathrm{c}}$ & 22 & $3.09^{b \uparrow}$ & 160 & $4.61^{\mathrm{a} \uparrow}$ \\
\hline & $\mathrm{CR}$ & $\mathrm{H}-$ & 11 & $2.48^{b}$ & 0 & $0.00^{c \downarrow}$ & 0 & $0.04^{\mathrm{b}}$ \\
\hline & & $\mathrm{H}+$ & 2 & $1.10^{\mathrm{d}}$ & 0 & $0.00^{c \downarrow}$ & 0 & $0.00^{b}$ \\
\hline
\end{tabular}

${ }^{1}$ different letters indicate significant differences at $p<0.05$; arrows indicate significant increase or decrease in relation to the previous date state.

Under CR-H+ treatment the weed biomass further decreased, after already being strongly reduced by the CR itself; in 1997 the crop was even completely deprived of the accompanying vegetation.

Throughout the experiment, Apera spica-venti L.) P. Beauv. and Centaurea cyanus L. were the most abundant and problem weed species in the winter rye fields.

Under CC-H-, Apera spica-venti L.) P. Beauv., with a biomass of over $40 \%$ of all weed biomass in all three studied years, had a relatively stable position of the most abundant dominant (Table S1). Centaurea cyanus L. with a slightly smaller biomass and a share of over $20 \%$ in the total weed biomass ranked second. These are highly competitive species with a developmental rhythm harmonised with that of winter cereals, which easily exploit the cereal's weakening by a long-term flawed crop sequence $[5,58]$.

The CR-H- treatment significantly limited the biomass of the above-mentioned two highly competitive species, in 1997 and 2017 completely eliminating C. cyanus L. from the field. The latter effect seems particularly important, as in $2017 \mathrm{CC}-\mathrm{H}+$ herbicide turned out to be ineffective against C.cyanus L., while the biomass of this species significantly increased in subsequent points in time. In all the studied years, the biomass of A.spica-venti L.) P. Beauv. under CC-H+ decreased compared to CC-H-, although in 2017 this reduction was significantly weaker than earlier. Recently in Poland, an increasing number of signals about the resistance of A.spica-venti L.) P. Beauv. and C.cyanus L. to herbicides have been recorded [61].

The role of crop rotation in weed control has been emphasized in the literature $[5,19,20,26,31,58,59]$. However, most studies on the role of crop rotation in weed suppression have looked at crop rotation in conventional agricultural systems with herbicides, so they primarily indicate the impact of varying the type of herbicide used, rather than other factors associated with crop rotation [59]. The rotation studies without herbicides have generally found that more diverse systems had a lower abundance of weeds — especially problem species—but a greater diversity of weed species [5,58,62].

\subsection{Weed Biodiversity}

In the studied years (1997 and 2017), a total of 27 weed species were identified. They were classified hierarchically into 25 genera, 13 families, 13 orders, 3 classes and 2 divisions (Table S2). In 1997 and 2017 in individual communities (i.e., on single plots) from 0 to 15 species appeared. 
In 1997 and 2017 there was no difference in $S$ between weed communities under CC-H- and CR-H- treatments, although biomass reduction under CR-H- was noted (Table 6). Weed biomass reduction without a decrease in weed species richness implies sustainable weed control [25,27]. Species richness $(S)$ was significantly reduced under both CC-H+ and CR-H+. According to Storkey et al. [27], many of the world's cropping systems are now afflicted by herbicide resistance to the point that weed diversity has declined; although, in many cases, weed biomass has not. This means that strong weed species have out-competed more sensitive species. Such an effect was noted in the study in 2017 under $\mathrm{CC}-\mathrm{H}+$.

Table 6. Weed biodiversity in winter rye fields.

\begin{tabular}{|c|c|c|c|c|c|c|}
\hline \multirow{3}{*}{$\begin{array}{l}\text { Biodiversity } \\
\text { Index }\end{array}$} & \multirow{3}{*}{$\begin{array}{l}\text { Cropping } \\
\text { System }\end{array}$} & \multirow{3}{*}{$\begin{array}{c}\text { Plant } \\
\text { Protection }\end{array}$} & \multicolumn{2}{|c|}{1997} & \multicolumn{2}{|c|}{2017} \\
\hline & & & \multicolumn{4}{|c|}{ Data } \\
\hline & & & Original & Transformed & Original & Transformed \\
\hline \multirow[t]{4}{*}{$S$} & $\mathrm{CC}$ & $\mathrm{H}-$ & $13.0^{a, 1}$ & & $11.3^{a}$ & \\
\hline & & $\mathrm{H}+$ & $3.3^{\mathrm{b}}$ & & $3.3^{b}$ & \\
\hline & CR & $\mathrm{H}-$ & $10.0^{\mathrm{a}}$ & & $12.3^{a}$ & \\
\hline & & $\mathrm{H}+$ & $0.3^{b}$ & & $4.0^{\mathrm{b} \uparrow}$ & \\
\hline \multirow[t]{4}{*}{$H^{\prime}$} & $\mathrm{CC}$ & $\mathrm{H}-$ & 1.37 & $0.86^{\mathrm{a}}$ & 1.15 & $0.76^{b}$ \\
\hline & & $\mathrm{H}+$ & 0.96 & $0.67^{\mathrm{a}}$ & 0.74 & $0.55^{\mathrm{b}}$ \\
\hline & CR & $\mathrm{H}-$ & 1.36 & $0.84^{\mathrm{a}}$ & 2.00 & $1.10^{\mathrm{a} \uparrow}$ \\
\hline & & $\mathrm{H}+$ & 0.00 & $0.00^{\mathrm{b}}$ & 0.94 & $0.65^{b \uparrow}$ \\
\hline \multirow[t]{4}{*}{$\Delta+$} & $\mathrm{CC}$ & $\mathrm{H}-$ & 4.42 & $2.10^{\mathrm{a}}$ & 4.66 & $2.16^{a, b}$ \\
\hline & & $\mathrm{H}+$ & 4.64 & $2.15^{\mathrm{a}}$ & 4.89 & $2.21^{\mathrm{a}}$ \\
\hline & CR & $\mathrm{H}-$ & 4.16 & $2.04^{\mathrm{a}}$ & 4.12 & $2.03^{b}$ \\
\hline & & $\mathrm{H}+$ & 0.00 & $0.00^{\mathrm{b}}$ & 4.56 & $2.14^{\mathrm{a}, \mathrm{b} \uparrow}$ \\
\hline \multirow[t]{4}{*}{$Q$} & $\mathrm{CC}$ & $\mathrm{H}-$ & 3.31 & $1.45^{\mathrm{a}, \mathrm{b}}$ & 2.22 & $1.17^{\mathrm{a}, \mathrm{b}}$ \\
\hline & & $\mathrm{H}+$ & 2.77 & $1.31^{\mathrm{b}}$ & 1.61 & $0.96^{\mathrm{b}}$ \\
\hline & $\mathrm{CR}$ & $\mathrm{Hc}$ & 4.84 & $2.04^{\mathrm{a}}$ & 4.19 & $1.58^{\mathrm{a}}$ \\
\hline & & $\mathrm{H}+$ & 0.00 & $0.00^{\mathrm{c}}$ & 2.35 & $1.17^{\mathrm{a}, \mathrm{b} \uparrow}$ \\
\hline
\end{tabular}

$\overline{1}$ different letters indicate significant differences at $p<0.05$; arrows indicate significant increase or decrease in relation to the previous date state.

In 1997, $H^{\prime}$ under CC-H-, CC-H+, and CR-H- did not differ, although a decrease of $H^{\prime}$ under CR-H+ was noted. In 2017, the CR-H- guaranteed higher $H^{\prime}$ in comparison to other treatments; in addition, $H^{\prime}$ increased in comparison with 1997 analysis.

Studies by other authors indicate a decrease in $H^{\prime}$ in continuous cereal cropping compared to diversified crop rotation [63], but also reverse relations were noted [64], as well as large fluctuations in time, depending on the applied weed regulation methods and the weather conditions [65]. For example, in a study by Feledyn-Szewczyk et al. [65], weed $S$ and $H^{\prime}$ in wheat grown in crop rotation (planned according to organic farming system) were normally higher than in continuous wheat (with chemical protection), but $H^{\prime}$ fluctuated to a greater extent, until a higher level was reached in continuous cropping than in crop rotation. The decrease in species diversity noted due to herbicide treatment is supported by other studies [66]. On the other hand, Mayerová et al. [25] found that, depending on the active substances or their combination, herbicide treatments can reduce the weed species diversity expressed by $H^{\prime}$, but may also not alter it.

In 1997, taxonomic distinctness $(\Delta+)$ of weed communities under CC-H-, CC-H+, and CR-Htreatments did not differ, but it was completely eliminated under CR-H+. In 2017, a decrease in $\Delta+$ was recorded in $\mathrm{CR}-\mathrm{H}-$, which was most likely a consequence of a significant decrease in the proportions of monocotyledons. 
In both studied years, CR-H- supported the maintenance of the weed community's functional diversity $(Q)$ in comparison to CC-H-. In 1997, a decrease in the $Q$ index was recorded under CR-H+. Weeds were completely eliminated under this treatment.

To date, the reaction of taxonomic and functional weed diversity to agricultural practices, including crop sequences, has rarely been studied [67-69]. It is therefore difficult to relate the current findings to other research.

In 1997, all the adopted biodiversity measures showed a strong mutual positive correlation (Table 7). In 2017, a significant positive correlation between $S$ and $H^{\prime}$, and a negative correlation between $H^{\prime}$ and $\Delta+$ was found. This issue also remains open. To compare, in a study by Otto et al. [70] on weed diversity in north-eastern Italy, $S, H^{\prime}$ and $Q$ (both based on weed density) were uncorrelated.

Table 7. Relationship between weed biodiversity indicators (original or transformed data respectively) showed in simple correlation coefficients.

\begin{tabular}{|c|c|c|c|c|}
\hline Biodiversity Index & Data & $S$ & $H^{\prime}$ & $\Delta+$ \\
\hline \multicolumn{5}{|c|}{1997} \\
\hline$H^{\prime}$ & original & $0.878 *$ & & \\
\hline \multirow{2}{*}{$\Delta+$} & original & $0.657 *$ & $0.871 *$ & \\
\hline & transformed & nc & 0.938 * & \\
\hline \multirow[t]{2}{*}{$Q$} & original & 0.770 * & 0.938 * & 0.863 * \\
\hline & transformed & nc & 0.977 * & 0.953 * \\
\hline \multicolumn{5}{|c|}{2017} \\
\hline$H^{\prime}$ & original & $0.817 *$ & & \\
\hline \multirow[t]{2}{*}{$\Delta+$} & original & -0.480 & $-0.748 *$ & \\
\hline & transformed & nc & $-0.783 *$ & \\
\hline \multirow[t]{2}{*}{$Q$} & original & 0.289 & 0.554 & -0.506 \\
\hline & transformed & nc & 0.549 & -0.508 \\
\hline
\end{tabular}

In 1997, biodiversity indicators showed a positive correlation with weed biomass, which was not confirmed in 2017 (Table 8). According to Gerowit et al. [71], since a high abundance of weeds provides a good chance for weed species diversity, higher species diversity is frequently found connected with higher weed density or biomass.

Table 8. Relationship between weed biomass and weed biodiversity (original or transformed data respectively) showed in simple correlation coefficients.

\begin{tabular}{cccc}
\hline Biodiversity Index & Data & $\mathbf{1 9 9 7}$ & $\mathbf{2 0 1 7}$ \\
\hline$S$ & original & $0.724^{*}$ & 0.029 \\
\hline$H^{\prime}$ & original & 0.560 & -0.401 \\
& transformed & $0.912^{*}$ & -0.112 \\
\hline$\Delta+$ & original & 0.527 & 0.486 \\
& transformed & $0.926^{*}$ & 0.327 \\
\hline$Q$ & original & 0.315 & -0.394 \\
& transformed & $0.865^{*}$ & -0.337 \\
\hline
\end{tabular}

${ }^{*}$ significant at $p<0.05$.

In the current study, higher similarity $(S I)$ between weed communities was often observed when only the presence/absence of species was considered and was very low when biomass produced by the species was taken into account (Table 9). The exception was the similarity between $\mathrm{H}-$ and $\mathrm{H}+$ 
within CC, where biomass-based SI was comparable (1997) or even markedly higher (2017) than presence/absence-based $S I$.

Table 9. Similarity coefficients (SI) of weed communities in winter rye fields.

\begin{tabular}{|c|c|c|c|c|c|}
\hline \multirow{3}{*}{ Within } & \multirow{3}{*}{ Between } & \multicolumn{4}{|c|}{ SI Based on Species } \\
\hline & & \multicolumn{2}{|c|}{ Presence/Absence } & \multicolumn{2}{|c|}{ Biomass } \\
\hline & & 1997 & 2017 & 1997 & 2017 \\
\hline $\mathrm{CC}$ & $-\mathrm{H}:+\mathrm{H}$ & 0.30 & 0.44 & 0.34 & 0.65 \\
\hline $\mathrm{CR}$ & $-\mathrm{H}:+\mathrm{H}$ & 0.14 & 0.54 & $0.00^{1}$ & 0.09 \\
\hline $\mathrm{H}-$ & CC:CR & 0.55 & 0.56 & 0.04 & 0.07 \\
\hline $\mathrm{H}+$ & CC:CR & 0.40 & 0.35 & 0.00 & 0.01 \\
\hline CC-H- & 1997:2017 & \multicolumn{2}{|c|}{0.69} & \multicolumn{2}{|c|}{0.69} \\
\hline $\mathrm{CC}-\mathrm{H}+$ & 1997:2017 & \multicolumn{2}{|c|}{0.55} & \multicolumn{2}{|c|}{0.25} \\
\hline CR-H- & $1997: 2017$ & \multicolumn{2}{|c|}{0.55} & \multicolumn{2}{|c|}{0.29} \\
\hline CR-H+ & 1997:2017 & \multicolumn{2}{|c|}{0.17} & \multicolumn{2}{|c|}{0.04} \\
\hline
\end{tabular}

Regardless of the calculation basis, when comparing the weed communities between years within the same treatments, the highest SIs for $\mathrm{CC}-\mathrm{H}$ - were recorded. This proves the relatively high stability over time of the weed community under the CC-H-. Under CC-H+ and CR-H- similar SI values for 1997:2017 comparison was obtained. Strong community limitation to single (random) species resulted in very low between year-SIs under CR-H+.

\subsection{Rye Yield and Yield Components}

It was well-documented earlier that growing crops in a diversified crop rotation is more beneficial for crop yields than continuous cropping of the same species in a single field [72-74]. In this context, the presented findings concerning rye cultivation are not surprising (Table 10). 
Table 10. Winter rye grain yield and yield components (relative numbers in brackets are \% of CC-H- effects).

\begin{tabular}{|c|c|c|c|c|c|}
\hline Parameter & Cropping System & Plant Protection & 1977 & 1997 & 2017 \\
\hline \multirow[t]{4}{*}{$\begin{array}{c}\text { Grain yield, } \\
\text { t/ha }\end{array}$} & $\mathrm{CC}$ & $\mathrm{H}-$ & $\begin{array}{c}2.10^{c, 1} \\
(100)\end{array}$ & $\begin{array}{c}3.82^{\mathrm{d} \uparrow} \\
(100)\end{array}$ & $\begin{array}{l}4.12^{\mathrm{c}} \\
(100)\end{array}$ \\
\hline & & $\mathrm{H}+$ & $\begin{array}{l}3.09^{\mathrm{b}} \\
(147)\end{array}$ & $\begin{array}{c}4.48^{\mathrm{c} \uparrow} \\
(117)\end{array}$ & $\begin{array}{l}4.76^{b} \\
(115)\end{array}$ \\
\hline & CR & $\mathrm{H}-$ & $\begin{array}{c}3.67^{\mathrm{a}} \\
(175)\end{array}$ & $\begin{array}{c}5.86^{\mathrm{a} \uparrow} \\
(153)\end{array}$ & $\begin{array}{c}7.08^{\mathrm{a} \uparrow} \\
(172)\end{array}$ \\
\hline & & $\mathrm{H}+$ & $\begin{array}{l}3.57^{a} \\
(170)\end{array}$ & $\begin{array}{c}4.97^{\mathrm{b} \uparrow} \\
(130)\end{array}$ & $\begin{array}{c}6.70 \mathrm{a} \uparrow \\
(163)\end{array}$ \\
\hline \multirow[t]{5}{*}{$\begin{array}{l}\text { Spike density, } \\
\text { No. } / \mathrm{m}^{2}\end{array}$} & $\mathrm{CC}$ & $\mathrm{H}-$ & $252^{b}$ & $418^{\mathrm{\uparrow}}$ & $331^{a}$ \\
\hline & & $\mathrm{H}+$ & $323^{a}$ & $596^{\mathrm{a} \uparrow}$ & $429 \mathrm{a} \downarrow$ \\
\hline & CR & $\mathrm{H}-$ & $327^{\mathrm{a}}$ & $529^{a, b \uparrow}$ & $425^{\mathrm{a}}$ \\
\hline & & $\mathrm{H}+$ & $315^{\mathrm{a}}$ & $483^{\mathrm{b}, \mathrm{c} \uparrow}$ & $381^{a}$ \\
\hline & $\mathrm{r}$ & & $0.922 *$ & 0.416 & 0.289 \\
\hline \multirow[t]{5}{*}{$\begin{array}{l}\text { Grains per } \\
\text { spike, No. }\end{array}$} & $\mathrm{CC}$ & $\mathrm{H}-$ & $30.3^{c}$ & $43.1^{\mathrm{a}, \mathrm{b} \uparrow}$ & $43.4^{\mathrm{a}}$ \\
\hline & & $\mathrm{H}+$ & $35.2^{b}$ & $42.0^{\mathrm{a}, \mathrm{b} \uparrow}$ & $41.1^{\mathrm{a}}$ \\
\hline & $\mathrm{CR}$ & $\mathrm{H}-$ & $38.8^{a}$ & $46.2^{\mathrm{a} \uparrow}$ & $45.2^{\mathrm{a}}$ \\
\hline & & $\mathrm{H}+$ & $40.4^{\mathrm{a}}$ & $38.5^{\mathrm{b}}$ & $48.4^{\mathrm{a} \uparrow}$ \\
\hline & $\mathrm{r}$ & & $0.960 *$ & 0.289 & 0.491 \\
\hline \multirow{5}{*}{$\begin{array}{l}\text { Weight of } \\
1000 \text { grains } \\
(\mathrm{TGW}), \mathrm{g}\end{array}$} & $\mathrm{CC}$ & $\mathrm{H}-$ & $27.0^{\mathrm{b}}$ & $34.4^{\mathrm{b} \uparrow}$ & $31.9^{b \downarrow}$ \\
\hline & & $\mathrm{H}+$ & $27.7^{\mathrm{a}, \mathrm{b}}$ & $31.6^{\mathrm{c} \uparrow}$ & $28.8^{\mathrm{c} \downarrow}$ \\
\hline & $\mathrm{CR}$ & $\mathrm{H}-$ & $29.3^{\mathrm{a}}$ & $37.0^{\mathrm{a} \uparrow}$ & $36.8^{a}$ \\
\hline & & $\mathrm{H}+$ & $28.7^{a, b}$ & $36.1^{\mathrm{a} \uparrow}$ & $36.3^{a}$ \\
\hline & $\mathrm{r}$ & & $0.785 *$ & $0.621 *$ & 0.854 * \\
\hline
\end{tabular}

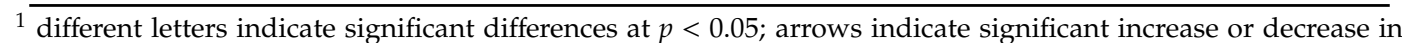
relation to the previous date state; $\mathrm{r}$ - simple correlation coefficient between grain yield and yield structure elements; ${ }^{*} \mathrm{r}$ significant at $p<0.05$.

At each of the successive selected points on the time axis of the current study, the rye yield was increasing and even the yield obtained in 1997 under CC exceeded the yield collected from the field under CR in 1977. However, this is a secondary matter to be attributed to genetic progress, the date (year) of the cultivar exchange and the impact of specific weather conditions on an individual vegetation season. As Herbst et al. [75] reported, the yield increase since 1920 was also noted in the Eternal Rye trial in Halle, caused mainly by the cultivation of new, higher-yielding cultivars and the regular use of plant protection products.

However, in current study, irrespective of the yield level in the years presented, it is worth noting that although the absolute difference between rye yield under CC-H- and CR-H- (yield protected by $\mathrm{CR}$ itself) increased over the years, the contrast between these cropping systems did not deepen in relative numbers. Such a result is in line with the so-called 'decline effect'. It manifests itself in a significant drop in crop yields in the initial years of continuous cropping and then in yield stabilisation in subsequent years, but at a lower level than if a diversified crop rotation had been applied [76]. Other authors argue that the degree of yield reduction under continuous cropping- besides its duration-depends on a number of factors, including soil type, weather conditions, fertilisation and crop protection [7,74]. According to earlier observations by Zawiślak et al. [74], higher rye yields were correlated with smaller differences between their levels under crop rotation and continuous cropping. Those findings were not confirmed by the current study.

Herbicides are a recognised soil fatigue-reducing factor in continuous cereal cropping [5,74]. In the current study, the CC-H+ treatment increased the rye yield in comparison to CC-H-, however, this protective effect weakened over the time. Earlier, in the same experiment, Adamiak [5] showed 
that herbicides used in 31-35-year-old continuous rye played a greater role in protecting yield than in 21-25-year-old continuous rye. The current findings from a longer study perspective are in opposition to the abovementioned ones. This may also be related to active ingredients and the mode of action of applied herbicides and to the prevailing weather conditions and cereal tolerance to herbicide toxicity. The current study shows that the application of $\mathrm{H}+$ to yield protection under CR was needless (1977, 2017) and even harmful (1997).

In 1977, the CR-H- treatment improved all three yield components compared to CC-H-. The $\mathrm{CC}-\mathrm{H}+$ increased the spike density to a level guaranteed by $\mathrm{CR}-\mathrm{H}-$, and also significantly improved the grain number per spike and the weight of 1000 grains (TGW). In 1997, in comparison to CC-H-, the CR-H- treatment improved the values of all yield structure elements and CC-H+ was effective in improving spike density, but reduced the TGW. The CR-H+ treatment showed a tendency to decrease spike density and grain number per spike. In 2017, experimental factors did not affect spike density and grain number per spike, but significantly influenced TGW. The CC-H+ treatment significantly improved TGW against CC-H-, but the increase did not equal the positive effect of CR-H-. TGW under CR-H+ and CR-H- did not differ in 2017.

In 1977, all three rye yield structure elements showed a strong positive correlation with rye yield, whereas in 1997 and 2017 only a positive correlation between yield and TGW was confirmed.

As regards the yield structure elements' contribution to the yield reduction under continuous rye cropping, different opinions of the authors can be found, which may be related both to the experiments' duration and to the overlapping of other research factors $[72,74,77]$. On the basis of numerous experiments, Zawiślak et al. [74] claimed that under continuous rye cropping there were slight negative changes in the yield structure, and that the plant density, the grain number per spike and TGW decreased relatively evenly, which corresponds to the 1977 study (correlation analysis, Table 10). However, the results for 1997 and 2017 are consistent with the reports by Parylak and Oliwa [78].

In each of the years studied, the yield correlated strongly negatively with the total weed biomass, as well as with the biomass of the two main competitors, i.e., A.spica-venti L.) P. Beauv. and C.cyanus L. (Table 11). Reducing dominance, especially of grass species, and increasing the weed variability in growth forms and heights seems to be the key for sustainable yield protection $[25,79]$. The results of our research confirm that this can be achieved by crop rotation.

Table 11. Relationship winter rye yield and weed biomass (original or transformed data respectively) shown as simple correlation coefficients.

\begin{tabular}{ccccc}
\hline Weed Biomass & Data & $\mathbf{1 9 7 7}$ & $\mathbf{1 9 9 7}$ & $\mathbf{2 0 1 7}$ \\
\hline Total & $\begin{array}{c}\text { original } \\
\text { transformed }\end{array}$ & $-0.728^{*}$ & $-0.709 *$ & $-0.925^{*}$ \\
& original & $-0.923^{*}$ & -0.367 & $-0.840^{*}$ \\
\hline $\begin{array}{c}\text { Apera spica venti L.) } \\
\text { P. Beauv. }\end{array}$ & transformed & $-0.812 *$ & $-0.772 *$ & $-0.899 *$ \\
& $\begin{array}{c}\text { original } \\
\text { Centaurea cyanus L. }\end{array}$ & $-0.877^{*}$ & $-0.752^{*}$ & $-0.955^{*}$ \\
\hline & transformed & $-0.796^{*}$ & $-0.887^{*}$ & $-0.946^{*}$ \\
\hline
\end{tabular}

* significant at $p<0.05$.

No significant correlation between rye yield and weed biodiversity was found in any of the years studied (data not shown). Previous studies have shown that a weed community consisting of a few weed species is often more harmful than a community consisting of a dozen or more components [80]. However, evidence of a positive relationship between weed diversity indicators and crop productivity can rarely be found in the literature $[79,81,82]$.

\section{Conclusions}

Growing rye under diversified crop rotation with no chemical protection guaranteed a satisfactory yield level and limited the weeds' biomass—especially problem species—without a decrease in weed 
species diversity and functional diversity. Crop rotation tended to reduce the taxonomic diversity of weeds. When rye was grown under crop rotation, the herbicide application was useless in yield improvement and weed competition reduction, but harmful to weed biodiversity. The rye yield correlated strongly negatively with the total weed biomass and the biomass of A.spica-venti L.) P. Beauv. and C.cyanus L., but did not show a relationship with weed biodiversity. No convincing links were established between the different dimensions of weed biodiversity and between weed biomass and weed biodiversity. Long-term continuous cropping is a valuable background for the recognition of the multiplicity of crop rotation functions.

Supplementary Materials: The following are available online at http://www.mdpi.com/2073-4395/9/10/644/s1, Table S1: Average proportion (\%) of weed species biomass in the years TABLE

Author Contributions: Conceptualization, M.J. and M.K.K.; methodology M.J. and M.K.K.; validation, M.J., M.K.K., M.M. and W.P.J.; formal analysis, M.J.; investigation, M.J., M.K.K., K.T. and P.M.; writing—original draft preparation, M.J.; writing—-review and editing, M.K.K., M.M. and W.P.J.; visualization, M.J.

Funding: This research received no external funding.

Acknowledgments: Andrzej Kosecki and other employees from the Production and Experimental Plant 'Bałcyny' Sp. z o.o. are highly acknowledged for their technical support during this long-term experiment.

Conflicts of Interest: The authors declare no conflict of interest.

\section{References}

1. Stein, S.; Steinmann, H.-H. Identifying crop rotation practice by the typification of crop sequence patterns for arable farming systems-A case study from Central Europe. Eur. J. Agron. 2018, 92, 30-40. [CrossRef]

2. Plourde, J.D.; Pijanowski, B.C.; Pekin, B.K. Evidence for increased monoculture cropping in the Central United States. Agric. Ecosyst. Environ. 2013, 165, 50-59. [CrossRef]

3. Kuś, J. Znaczenie płodozmianu we współczesnym rolnictwie. In Wybrane Problemy Produkcji Rolniczej z Uwzględnieniem Aspektu Dóbr Publicznych; IUNG-PIB Puławy: Puławy, Poland, 2015; pp. 65-88.

4. Barbieri, P.; Pellerin, S.; Nesme, T. Comparing crop rotations between organic and conventional farming. Sci. Rep. 2017, 7, 13761. [CrossRef] [PubMed]

5. Adamiak, E. Struktura zachwaszczenia i produktywność wybranych agrocenoz zbóż ozimych i jarych w zależności od systemu następstwa roślin i ochrony łanu; Wydawnictwo Uniwersytetu Warmińsko-Mazurskiego: Olsztyn, Poland, 2007; Volume 129, p. 146.

6. Stępień, W.; Kobiałka, M. Effect of long-term organic and mineral fertilisation on selected physico-chemical soil properties in rye monoculture and five-year crop rotation. Soil Sci. Annu. 2019, 70, 34-38. [CrossRef]

7. Blecharczyk, A.; Piechota, T.; Malecka, I. Zmiany chemicznych wlasciwosci gleby w wyniku wieloletniego oddzialywania systemow nastepstwa roslin i nawozenia. Frag. Agron. 2005, 2, 30-38.

8. Ryszkowski, L.; Szajdak, L.; Karg, J. Effects of continuous cropping of rye on soil biota and biochemistry. Crit. Rev. Plant Sci. 1998, 17, 225-244. [CrossRef]

9. Ekologiczne Procesy w Monokulturowych Uprawach Zbóż; Ryszkowski, L.; Karg, J.; Pudełko, J. (Eds.) Wydawnictwo Naukowe UAM: Poznań; Poland, 1990; p. 238.

10. Kurowski, T.P. Studia nad Chorobami Podsuszkowymi zboz Uprawianych w Wieloletnich Monokulturach; Uniwersytet Warmińsko-Mazurski w Olsztynie: Olsztyn; Poland, 2002.

11. Rychcik, B.; Adamiak, J.; Wójciak, H. Dynamics of the soil organic matter in crop rotation and long-term monoculture. Plant Soil Environ. 2006, 52, 15-20.

12. Blecharczyk, A. Reakcja zyta ozimego i jeczmienia jarego na system nastepstwa roslin i nawozenie w doswiadczeniu wieloletnim. Rocz. Ar Poznań. Rozpr. Nauk. 2002, 326, 1-127.

13. Körschens, $\mathrm{M}$. The importance of long-term field experiments for soil science and environmental research-A review. Plant Soil Environ. 2006, 52, 1-8.

14. Johnston, A.E.; Poulton, P.R. The importance of long-term experiments in agriculture: their management to ensure continued crop production and soil fertility; the Rothamsted experience. Eur. J. Soil Sci. 2018, 69, 113-125. [CrossRef]

15. Niewiadomski, W. Nauka o płodozmianach-Stan i perspektywy. Post. Nauk Rol. 1995, 3, 127-139. 
16. Merbach, W.; Deubel, A. Long-term field experiments-Museum relics or scientific challenge? Plant Soil Environ. 2008, 54, 219-226. [CrossRef]

17. Eksperymenty Wieloletnie w Badaniach Rolniczych w Polsce-Long-Term Experiments in Agricultural Studies in Poland; Marks, M.; Jastrzębska, M.; Kostrzewska, M.K. (Eds.) Wydawnictwo Uniwersytetu Warmińsko-Mazurskiego w Olsztynie: Olsztyn; Poland, 2018; p. 280.

18. Gill, H.K.; Garg, H. Pesticides: environmental impacts and management strategies. In Pesticides-Toxic Aspects; IntechOpen: London, UK, 2014; pp. 187-230.

19. Boyabatli, O.; Nasiry, J.; Zhou, Y.H. Crop planning in sustainable agriculture: Dynamic farmland allocation in the presence of crop rotation benefits. Manag. Sci. 2019, 65, 2060-2076. [CrossRef]

20. Brankatschk, G.; Finkbeiner, M. Crop rotations and crop residues are relevant parameters for agricultural carbon footprints. Agron. Sustain. Dev. 2017, 37, 58. [CrossRef]

21. Schumacher, M.; Ohnmacht, S.; Rosenstein, R.; Gerhards, R. How management factors influence weed communities of cereals, their diversity and endangered weed species in central Europe. Agriculture 2018, 8 , 172. [CrossRef]

22. Zimdahl, R.L. Weeds: The Beginning. In Fundamentals of Weed Science, 5th ed.; Zimdahl, R.L., Ed.; Elsevier: Amsterdam, The Netherlands, 2018; pp. 17-46.

23. Blaix, C.; Moonen, A.C.; Dostatny, D.F.; Izquierdo, J.; Le Corff, J.; Morrison, J.; Von Redwitz, C.; Schumacher, M.; Westerman, P.R. Quantification of regulating ecosystem services provided by weeds in annual cropping systems using a systematic map approach. Weed Res. 2018, 58, 151-164. [CrossRef]

24. Marshall, E.J.P.; Brown, V.K.; Boatman, N.D.; Lutman, P.J.W.; Squire, G.R.; Ward, L.K. The role of weeds in supporting biological diversity within crop fields. Weed Res. 2003, 43, 77-89. [CrossRef]

25. Mayerová, M.; Mikulka, J.; Soukup, J. Effects of selective herbicide treatment on weed community in cereal crop rotation. Plant Soil Environ. 2018, 64, 413-420. [CrossRef]

26. Nikolich, L.; Milosev, D.; Seremesich, S.; Dalovich, I.; Vuga-Janjatov, V. Diversity of weed flora in wheat depending on crop rotation and fertilisation. Bulg. J. Agric. Sci. 2012, 18, 608-615.

27. Storkey, J.; Neve, P. What good is weed diversity? Weed Res. 2018, 58, 239-243. [CrossRef]

28. Zając, M.; Zając, A.; Tokarska-Guzik, B. Extinct and endangered archaeophytes and the dynamics of their diversity in Poland. Biodiv. Res. Conserv. 2009, 13, 17-24. [CrossRef]

29. Meyer, S.; Wesche, K.; Krause, B.; Leuschner, C. Dramatic losses of specialist arable plants in Central Germany since the 1950s/60s-A cross-regional analysis. Divers. Distrib. 2013, 19, 1175-1187. [CrossRef]

30. Wright, H.L.; Lake, I.R.; Dolman, P.M. Agriculture-a key element for conservation in the developing world. Conserv. Lett. 2012, 5, 11-19. [CrossRef]

31. Koocheki, A.; Nassiri, M.; Alimoradi, L.; Ghorbani, R. Effect of cropping systems and crop rotations on weeds. Agron. Sustain. Dev. 2009, 29, 401-408. [CrossRef]

32. Jastrzębska, M.; Jastrzębski, W.P.; Hołdyński, C.; Kostrzewska, M.K. Weed species diversity in organic and integrated farming systems. Acta Agrobot. 2013, 66, 113-124. [CrossRef]

33. Warwick, R.M. Average taxonomic diversity and distinctness. In Encyclopedia of Ecology, Five-Volume Set; Elsevier Inc.: Amsterdam, The Netherlands, 2008; pp. 300-305.

34. Feledyn-Szewczyk, B. Changes of biodiversity of weed flora in organic system in the years 1996-2007. J. Res. Appl. Agric. Eng. 2008, 53, 63-68.

35. Warwick, R.M.; Clarke, K.R. New "biodiversity" measures reveal a decrease in taxonomic distinctness with increasing stress. Mar. Ecol. Prog. Ser. 1995, 129, 301-305. [CrossRef]

36. Tilman, D. Functional Diversity. In Encyclopedia of Biodiversity: Second Edition; Elsevier Inc.: Amsterdam, The Netherlands, 2013; pp. 587-596.

37. Loreau, M.; Naeem, S.; Inchausti, P.; Bengtsson, J.; Grime, J.P.; Hector, A.; Hooper, D.U.; Huston, M.A.; Raffaelli, D.; Schmid, B.; et al. Ecology: Biodiversity and ecosystem functioning: Current knowledge and future challenges. Science 2001, 294, 804-808. [CrossRef]

38. Schleuter, D.; Daufresne, M.; Massol, F.; Argillier, C. A user's guide to functional diversity indices. Ecol. Monogr. 2010, 80, 469-484. [CrossRef]

39. Petchey, O.L.; Gaston, K.J. Functional diversity: Back to basics and looking forward. Ecol. Lett. 2006, 9, 741-758. [CrossRef] 
40. Lemerle, D.; Storrie, A.; Panetta, F.D. The potential role of weed functional groups in cropping systems in weed management: balancing people, planet, profit. In Proceedings of the 14th Australian Weeds Conference, Wagga Wagga, NSW, Australia, 6-9 September 2004; pp. 133-135.

41. Storkey, J. A functional group approach to the management of UK arable weeds to support biological diversity. Weed Res. 2006, 46, 513-522. [CrossRef]

42. Jastrzębska, M.; Wanic, M.; Kostrzewska, M.K. Influence of crop rotation and meteorological conditons on biodiversity of weed communities in spring barley (Hordeum vulgare L.). Acta Agrobot. 2010, 63, 221-233. [CrossRef]

43. Marks, L. Pleistocene glacial limits in the territory of Poland. Przegl. Geol. 2005, 53, 988-993.

44. Woś, A. Klimat Polski; Wydaw. Naukowe PWN: Warsaw, Poland, 1999.

45. Hutorowicz, H.; Grabowski, J.; Olba-Zięty, E. Frequency of occurrence of dry spells and droughts in two mesoregions of Masurian Lakeland. Acta Agrophys. 2008, 12, 663-673.

46. Czernecki, B.; Miętus, M. The thermal seasons variability in Poland, 1951-2010. Appl. Clim. 2017, 127, 481-493. [CrossRef]

47. Grabowski, J. Charakterystyka stosunków termicznych występujących w Rolniczym Zakładzie Doświadczalnym w Bałcynach w latach 1972-1990. Acta Acad. Agric. Tech. Olst. Agric. 1995, 60, 3-13.

48. Spellerberg, I.F.; Fedor, P.J. A tribute to Claude Shannon (1916-2001) and a plea for more rigorous use of species richness, species diversity and the 'Shannon-Wiener'Index. Glob. Ecol. Biogeogr. 2003, 12, 177-179. [CrossRef]

49. Rao, C.R. Diversity and dissimilarity coefficients: A unified approach. Popul. Biol. 1982, 21, 24-43. [CrossRef]

50. Mirek, Z.; Piekos-Mirkowa, H.; Zajac, A.; Zajac, M. Flowering Plants and Pteridophytes of Poland. A checklist; W. Szafer Institute of Botany, PAN: Krakow, Poland, 2002.

51. Kleyer, M.; Bekker, R.M.; Knevel, I.C.; Bakker, J.P.; Thompson, K.; Sonnenschein, M.; Poschlod, P.; Van Groenendael, J.M.; Klimeš, L.; Klimešová, J.; et al. The LEDA Traitbase: A database of life-history traits of the Northwest European flora. J. Ecol. 2008, 96, 1266-1274. [CrossRef]

52. Paradowski, A.; Błażewicz-Woźniak, M. Atlas Chwastów; Plantpress: Krakow, Poland, 2013.

53. Zarzycki, K.; Trzcińska-Tacik,, H.; Różański, W.; Szeląg, Z.; Wołek, J.; Korzeniak, U. Ecological Indicator Values of Vascular Plants of Poland; W. Szafer Institute of Botany, Polish Academy of Sciences: Kraków; Poland, 2002; Volume 2, p. 183.

54. Ellenberg, H. Indicator values of vascular plants in central Europe. Scr. Geobot. 1974, 9, 1-97.

55. Sørensen, T.J. A method of Establishing Groups of Equal Amplitude in Plant Sociology Based on Similarity of Species Content and Its Application to Analyses of the Vegetation on Danish Commons; I kommission hos, E. Munksgaard: Copenhagen, Danmark, 1948; Volume 5, p. 34.

56. StatSoft Inc. Statistica (Data Analysis Software System), Version 12; StatSoft Inc.: Tulsa, OK, USA, 2014.

57. Microsoft Corporation. Microsoft Exel 2010; 14.0.4760.1000; Microsoft Corporation: Redmond, WA, USA, 2010.

58. Adamiak, E.; Zawiślak, K. Zmiany w zbiorowiskach chwastów w monokulturowej uprawie podstawowych zbóż i kukurydzy. In Ekologiczne Procesy w Monokulturowych Uprawach Zbóż; Ryszkowski, L., Karg, J., Pudełko, J., Eds.; Wydawnictwo Naukowe UAM: Poznań, Poland, 1990; pp. 47-75.

59. Mohler, C.L. The role of crop rotation in weed management. In Crop Rotation on Organic Farms: A Planning Manual; Mohler, C.L., Johnson, S.E., Eds.; Plant and Life Sciences Publishing: Ithaca, NY, USA, 2009; pp. 44-46.

60. Mahn, E.G. Structural changes of weed communities and populations. Vegetatio 1984, 58, 79-85. [CrossRef]

61. Adamczewski, K.; Matysiak, K.; Kierzek, R.; Kaczmarek, S. Significant increase of weed resistance to herbicides in Poland. J. Plant. Prot. Res. 2019, 59, 139-150. [CrossRef]

62. Mahaut, L.; Gaba, S.; Fried, G. A functional diversity approach of crop sequences reveals that weed diversity and abundance show different responses to environmental variability. J. Appl. Ecol. 2019, 56, 1400-1409. [CrossRef]

63. Stevenson, F.C.; Légère, A.; Simard, R.R.; Angers, D.A.; Pageau, D.; Lafond, J. Weed species diversity in spring barley varies with crop rotation and tillage, but not with nutrient source. Weed Sci. 1997, 45, 798-806. [CrossRef]

64. Wesołowski, M.; Jędruszczak, M.; Cierpiała, R. Organizacja zbiorowiska chwastów w zależności od systemu uprawy dwóch odmian pszenicy ozimej. Acta Agrophys. 2003, 1, 787-793. 
65. Feledyn-Szewczyk, B.; Kuś, J.; Stalenga, J.; Berbeć, A.K.; Radzikowski, P. The role of biological diversity in agroecosystems and organic farming. In Organic Farming - A Promising Way of Food Production; IntechOpen: London, UK, 2016.

66. Edesi, L.; Järvan, M.; Adamson, A.; Lauringson, E.; Kuht, J. Weed species diversity and community composition in conventional and organic farming: A five-year experiment. Zemdirbyste 2012, 99, 339-346.

67. Borgy, B.; Perronne, R.; Kohler, C.; Grison, A.L.; Amiaud, B.; Gaba, S. Changes in functional diversity and intraspecific trait variability of weeds in response to crop sequences and climate. Weed Res. 2016, 56, 102-113. [CrossRef]

68. Pallavicini Fernández, Y.d.l.Á. Effect of Agricultural Intensification on Taxonomic and Functional Diversity of Weed Communities in Cereal Fields; Universidad de Córdoba, UCOPress: Córdoba, Spain, 2016.

69. Alarcón Víllora, R.; Hernández Plaza, E.; Navarrete, L.; Sánchez, M.J.; Sánchez, A.M. Climate and tillage system drive weed communities' functional diversity in a Mediterranean cereal-legume rotation. Agric. Ecosyst. Environ. 2019, 283, 106574. [CrossRef]

70. Otto, S.; Vasileiadis, V.P.; Masin, R.; Zanin, G. Evaluating weed diversity with indices of varying complexity in north-eastern Italy. Weed Res. 2012, 52, 373-382. [CrossRef]

71. Gerowitt, B.; Bàrberi, P.; Darmency, H.; Petit, S.; Storkey, J.; Westerman, P. Weeds and biodiversity. In Weed Research: Expanding Horizons; Wiley: London, UK, 2017; pp. 115-147.

72. Parylak, D.; Sebzda, J.; Kordas, L. Long-term influence of cereal crop rotation on the properties of light soil and winter rye yield. Acta Agrophys. 2001, 52, 201-208.

73. Blecharczyk, A.; Malecka, I.; Pudelko, J.; Piechota, T. Effect of long-term fertilization and cropping systems on yield and macroelements content in winter rye. Ann. UmcsSec. E Agric. 2004, 59, 181-188.

74. Zawiślak, K.; Adamiak, J.; Gawrońska-Kulesza, A.; Pudełko, J.; Blecharczyk, A. Plonowanie podstawowych zbóż i kukurydzy w monokulturach. In Ekologiczne Procesy w Monokulturowych Uprawach zbóż; Ryszkowski, L., Karg, J., Pudełko, J., Eds.; Wydawnictwo Naukowe UAM: Poznań; Poland, 1990; pp. 197-222.

75. Herbst, F.; Schmidt, L.; Merbach, W. Development of the level of yields in eternal rye trial in Halle/s. (Germany) since 1879. J. Fur Kult. 2017, 69, 189-197. [CrossRef]

76. Szajdak, L.W.; Życzyńska-Bałoniak, I.; Wegner, K. Free, bounded, and included in humic acids amino acids: Thermal properties of humic acids from cropping systems. In Bioactive Compounds in Agricultural Soils; Springer International Publishing: Cham, Switzerland, 2016; pp. $25-52$.

77. Chmielewski, F.M.; Köhn, W. Impact of weather on yield components of winter rye over 30 years. Agric. For. Meteorol. 2000, 102, 253-261. [CrossRef]

78. Parylak, D.; Oliwa, T. Wpływ zróżnicowanej uprawy roli na warunki siedliskowe i plonowanie żyta ozimego w wieloletniej monokulturze. Zesz. Nauk. Ar WrocławRol. 1998, 69, 115-123.

79. Hernández Plaza, M.E.; Bastida, F.; Pallavicini, Y.; Izquierdo, I.; González-Andújar, J.L. Relationship between weed diversity and crop yield in Spanish wheat fields. Proceedings of 6th meeting of the EWRS working group "Weeds and biodiversity", Riga, Latvia, 26-29 September 2016.

80. Stupnicka-Rodzynkiewicz, E.; Stepnik, K.; Lepiarczyk, A. Wpływ zmianowania, sposobu uprawy roli i herbicydów na bioróżnorodność zbiorowisk chwastów. Acta Sci. Pol. Agric. 2004, 3, 235-245.

81. Kamoshita, A.; Araki, Y.; Nguyen, Y.T.B. Weed biodiversity and rice production during the irrigation rehabilitation process in Cambodia. Agric. Ecosyst. Environ. 2014, 194, 1-6. [CrossRef]

82. Ka, S.L.; Gueye, M.; Mbaye, M.S.; Kanfany, G.; Noba, K. Response of a weed community to organic and inorganic fertilization in peanut crop under Savannah zone of Senegal, West Africa. J. Res. Weed Sci. 2019, 2, 241-252. [CrossRef]

(C) 2019 by the authors. Licensee MDPI, Basel, Switzerland. This article is an open access article distributed under the terms and conditions of the Creative Commons Attribution (CC BY) license (http://creativecommons.org/licenses/by/4.0/). 